\title{
Post-Olypmic Economic Risk Analysis and Avoidance measures -- Taking Tokyo Olympic Games as an Example
}

\author{
Enhan Shuang ${ }^{1, *}$ Leicheng zhang ${ }^{1}$
}

\author{
${ }^{1}$ Nanjing University Of Finance \& Economics, Nanjing City, Jiangsu Province, China, 210000 \\ ${ }^{I}$ new channel qingdao, qingdao City, Shandong province, China \\ *Corresponding author. Email:893006944@qq.com
}

\begin{abstract}
With the preparation for the 2020 Tokyo Olympic Games, the rapid development of economic modernization in Tokyo and Japan has been greatly accelerated. The hosting of the Olympic Games will bring large-scale investment to the host country, stimulate the rapid growth of consumer demand, improve the employment of labor force, and have a huge economic effect. But it should not be overlooked that the economic challenges posed by the Games are longterm. Generally speaking, the follow-up effect will continue for 2-4 years after the End of the Olympic Games, because the economic development of the host city and even the whole country may slow down after the Olympic Games. This paper will analyze the economic risks brought by the post-Tokyo Olympic Games and offer some measures to avoid the economic risks.
\end{abstract}

Keywords: Post-Olympic Games, Economic risk, Tokyo Olympics, Trough effect

\section{INTRODUCTION}

Olympic Economy has always been the focus of attention from all walks of life, the Olympic Games has become a unique economic phenomenon in the development of the world economy, with the end of each Olympic Games will enter the post-Olympic era, the economic trough effect brought by the post-Olympic era is inevitable. We will draw lessons from the successful experience and failure of economic risk avoidance in the post-Olympic era, and on this basis, analyze the economic risk and avoidance measures in the post-Olympic era of the upcoming Tokyo Olympic Games. The reason that this topic has been chosen is because that there are many failures after the Olympic Games. The construction of venues costs a lot, and the operation is not good after the end of the activity, which affects the economic development of the city. Due to the loess the control of investment, the cost of the Olympic Games might be out of the budget. We can see from history that many past Olympic Games had issues like that.

\section{THE ECONOMIC IMPLICATION OF "POST-OLYMPIC ECONOMY"}

"Olympic Economy" refers to all economic connections and economic effects generated by all kinds of activities carried out around the Olympic Games in quite a period of time. Its cyclical and phased characteristics will make the Investment of the Olympic Games boost the economic growth of the host city and the host country before the Games, but will also face the negative impact of sudden slowdown or interruption of investment on economic growth after the games[1]. The "Olympic economy" can be divided into three economic stages, namely "pre-Olympic economy", "Mid-Olympic economy" and "post-Olympic economy".

From the bidding, preparation to the end of the Olympic Games, the sustained economic effect of the Olympic Games during this period is about 10-12 years. The Economy of Olympic Games can be divided into three stages: "pre-Olympic economy", "Mid-Olympic Economy" and "post-Olympic economy". "Pre-Olympic economy" is mainly the economic effect of Olympic Games during the period from the successful bid to the holding of the Olympic Games, especially in the first 
two years of the Olympic Games. The "pre-Olympic economy" effect refers to the positive effect of "cohesion effect", "radiation effect", "instant amplification effect" and the negative effect of "foundation effect" and "siphon effect" generated by the activities of "pre-Olympic economy"[2].For example, the IOC and the Olympic host city organizing Committee plan, finance and design for the successful hosting of the Olympic Games, the infrastructure construction of the host city and the construction of the Olympic Stadium. "China Olympic Economy" mainly refers to the economic effects generated during the Olympic Games, mainly economic gains or losses directly or indirectly related to the Olympic Games.

The "China Olympic Economy" effect lasts the shortest, usually during the Olympic Games.

The so-called post-Olympic economy is a general term for all economic activities and economic effects that have a direct or brief relationship with the Olympic Games in the host city and the host country during a considerable period of time after the Olympic Games. From integrated theory and practice of the Olympic Games before the "Olympic economy" and "Olympic economy" brought about by the economic effects on the whole is positively to, namely in the Olympic bid success until the Olympic Games during the period of activity is beneficial to the host city and host country's economic development, brought about by the economic profit is positive, However, the "post-Olympic economy" effect is usually negative, that is, the economic benefits brought by the host city and the host country for a considerable period of time after the Olympic Games are negative.

The overall effect of Olympic economy is the sum of "pre-Olympic economy", "Mid-Olympic economy" and "post-Olympic economy", and the positive economic effect is greater than the negative economic effect.

\section{ANALYSIS ON THE HARM OF THE TROUGH EFFECT OF "POST-OLYMPIC ECONOMY" AND ITS CAUSES}

After the Olympics, there will be an economic downturn. For example, during the Olympics, infrastructure wasted and idle, the Olympic host city, the price of venues fell, the economic growth of the stock market slowed down overall or partially, and even showed negative growth of global or local economic growth. Due to the high investment before the Olympics, the underutilization of stadiums and infrastructure after the Olympics also brought economic risks. At the same time, the economic risks brought about by the sharp fall in the prices of the real estate industry after the Olympics, especially the structural economic risks of the diversified development of the host city [3]. Therefore, the "post-Olympic economic risk" is the economic gap caused by a series of maintenance measures that accompany the initial investment, scale, and end of the Olympic Games.

The economic harm of the "post-Olympic economy" to the host city is mainly reflected in the following points: First, the post-Olympic economic effect reduces the economic demand of the host city after the Olympics. The second is the construction of a large number of related infrastructure before the Olympic Games. After the Olympics, the demand for a series of related facilities such as a large number of stadiums, venues, hotels, etc. decreased or even stopped. In the early stage of the Olympic Games, the host city built a large number of real estate industries, leading to a sharp increase in industry prices. After the Olympics, prices in the real estate industry have generally risen. Fourth, the host country or the host city may have a fiscal deficit, causing it to be heavily indebted. The fifth is the uneven regional development. Before and after the Olympic Games, in order to fully support the success of the Olympic Games, the host country will invest a large amount of funds, manpower, material resources and other resources into the construction and development of the host city. Under such circumstances, it will inevitably aggravate the uneven, uncoordinated, and economic gaps in regional development.

\section{CASE ANALYSIS}

\subsection{Failure Cases}

The 1976 Montreal Olympics were the most moneylosing games in Olympic history, with Montreal's citizens sharing the tax bill for nearly 30 years. The city spent nearly $\$ 1$ billion on the main stadium alone, and many of the stadiums were never finished after the Games because of corruption by IOC officials. The Games were boycotted by African countries, and only 88 Colombian countries took part, far fewer than in previous games. The Montreal Olympics was a typical example of over-investment in the early stage, which was lower than expected at the time of hosting, and after the Games ended due to the high management costs of a large number of venues, and most of the venues were left idle.The actual expenditure was 20 times more than 
the budget, so after 15 days of the Games, the government of Montreal was in the red, and the citizens of the host city began to pay off the debt slowly. For nearly 30 years, the citizens of Montreal have been paying off the debt for the financial deficit caused by the Games to the host city[4].

There are four main reasons for Montreal's failure. First, Montreal Municipal Government and Olympic Committee invested too much money in the early stage, and the revenue in the later stage did not reach the expectation. Second, African countries boycotted the Olympic Games, which resulted in African countries not participating in the Games. The scale was far less than that of previous Olympic Games. Third, corruption among government officials and members of the Olympic Committee has led to delays in infrastructure construction. Fourthly, in the early stage of the Olympic Games, a large number of infrastructure and sports hall construction, in the later stage of the stadium maintenance and maintenance is a great cost.

\subsection{Successful cases}

In 2009, according to the audit results released by The National Audit Bureau of China, the total expenditure of the Beijing Olympic Games was 20.206 billion US dollars, and the revenue was 21.363 billion US dollars, with the balance exceeding 1 billion US dollars. China made a profit of 1.157 billion US dollars from the 2008 Beijing Olympic Games. Judging from the audit results, the commercial operation of 2008 Olympic Games is undoubtedly one of the most successful Olympic Games[5].

The success of the 2008 Beijing Olympic Games is inseparable from the bold and innovative business model, which mainly includes the following four points. First, the Olympic Games adopted the operation model of private and government cooperation. The combination of non-governmental and government, commercial operation and administrative command not only ensures sufficient funds, but also increases work efficiency. Second, the Beijing Olympic Games innovated and developed the transfer of network broadcasting rights. In the past, the Olympic Games were usually broadcast on TV. However, with the popularity of the Internet, more and more people watched the Live Broadcast of the Olympic Games on the Internet. In order to adapt to the situation of the Internet at that time, the Chinese Olympic Committee for the first time sold the TV broadcast rights and the network broadcast rights separately during the Olympic
Games. Third, Beijing Olympic Games mascot innovation and development of the industry chain.

In the past, there was usually only one mascot for the Olympic Games, but there are five mascots for the Beijing Olympic Games, which has a great advantage in the combination sales of mascots. Moreover, for China, which has a population of nearly one billion, the sales of mascots is an unknown number. Fourthly, after the End of the Beijing Olympic Games, the utilization of Olympic stadiums is high, a large number of international events are introduced, and the "Bird's Nest", "Water Cube" and other stadiums drive local tourism.

\section{POST-OLYMPIC ECONOMIC RISKS OF TOKYO OLYMPIC GAMES}

\subsection{Economic risks caused by idle venues and routine maintenance}

The "post-Olympic" economic risk of each Olympic Games in the past is the same risk, the idle stadiums, after the end of the Half month or so of the Olympic Games, usually idle stadiums, and the daily maintenance of the stadiums is also a great cost.

\subsection{Economic risks caused by COVID-19}

The Tokyo Government and the Olympic Committee have not been made more comfortable by the fact that the 2020 games have been postponed for reasons other than war as a result of the COVID-19 pandemic that has swept the world, but it has been made more difficult by bizarre scandals. The Tokyo Olympic Games had to be held empty in order to contain the virus as Japan's fourth full outbreak began.

The Tokyo Games cost a staggering \$15.4bn, double the original plan and one of the highest on record for hosting an Olympics, surpassing the $\$ 15 \mathrm{bn}$ cost of London 2012.The total cost of the Tokyo Olympics has been on the rise due to the epidemic, with infrastructure spending topping $\$ 3.5$ billion, according to a survey by Nomura Research Institute[6]. Operating, technical and maintenance costs are also high, each exceeding \$1 billion. After the Japanese government announced the postponement, a number of sponsors announced they were pulling their support[6].

Most of the 3.63 million tickets sold were refunded because of problems with empty venues, leaving the 
government with hundreds of millions of dollars to cover the shortfall.

\section{TOKYO OLYMPIC GAMES "POST- OLYMPIC" ECONOMIC RISK AVOIDANCE MEASURES}

\subsection{Reasonably control the investment demand in the early stage and adjust the economy in the later stage}

Investment demand is the main component of the total demand of a country, its amount and growth rate will directly affect the total demand of the country, thus affecting the national economy. With the progress of the Olympic Games, it is normal for investment demand to decline. The key is to maintain investment demand by other means. Therefore, a reasonable guarantee of investment demand before and after the Olympic Games will help ensure the stability of regional and national economic conditions.

\subsection{Use idle venues to introduce international high-level sports events}

History shows that the main reason for the trough effect of "post-Olympic economy" is that the stadiums are not fully utilized after the Olympic Games. After the Olympic Games, the stadium can not be fully used, resulting in idle, waste of resources, and the Olympic venues can be well used, mainly depends on the country's sports, culture, exhibition, tourism and other organized activities. Efforts should be made to introduce a large number of international sports events, and the Olympic Village could be converted into real estate for citizens to live in. The venue can also be transformed into a training base for domestic and foreign competitions, or as a venue for entertainment and exhibition.

\subsection{Take advantage of the venue to promote the development of local tourism}

To build a tourist center integrating scenic spots, catering and accommodation with the Olympic Park as the center. After the Games, unused facilities can be used as conference facilities, museums and exhibition centers. Provide venues and facilities for other recreational, commercial and cultural activities, which will inevitably attract people with different needs. In addition, the surrounding infrastructure of Olympic venues will be used to attract investment and reduce the economic trough effect brought by the end of the Olympic Games.

\subsection{Ensure the sound development of the industries that cause economic fluctuations in the early stage of the Olympic Games after the Olympic Games}

In order to avoid some related industries due to the economic depression of the late Olympic Games and be impacted, the relevant government departments should make early warning plans as soon as possible. For example, in previous Olympic Games, the local real estate industry is bound to be impacted at the later stage of the Olympic Games, so the government should monitor the real estate index system and the real estate market early warning system as soon as possible, and make proper macro-control through the market detection of the real estate, so as to control the development of the real estate market on the whole.

\subsection{Actively carry out COVID-19 epidemic prevention and control to avoid unnecessary losses}

Tokyo Olympic Games unlike past Olympics is held in the context of new crown outbreaks, so that once again the risk of a pandemic is inevitable, the Tokyo Olympic Games in the nearly 12000 people, more than 180 are from different countries, and the third pandemic outbreaks in Japan needs to be controlled under the premise of contestants from different countries. The Tokyo government will certainly need to do a good job of containment during the Olympics in order not to lose money from containment efforts.

\subsection{Make use of the Golden signboard of Olympic Games}

Hosting the Olympic Games is a way for the host country and the host region to reach out to the world and let the world know about the region. It is also an opportunity to enhance its influence in the international arena. Japan's bid and hosting of the Olympic Games have received sustained attention from western media. Such long-term and high-frequency reports play an important role in expanding Japan's international influence and establishing a national brand[7].The Japanese government should make more use of the Tokyo Olympics to promote the development of local 
enterprises by bringing Japanese industries into the eyes of the global audience.

\section{CONCLUSION}

This paper analyzes the economic risks after the Olympics, and uses the Tokyo Olympics and the Beijing Olympics as examples to analyze their respective successes and failures. After the Olympics, the economic needs of the city, infrastructure construction, poverty, and regional development imbalance have been reduced. As for the measures to avoid economic risks after the Olympics, this article also summarizes the following: First, control the initial investment. Second, try to make use of the idle venues after the game as much as possible. Third, give full play to the advantages of venues to promote the development of tourism. Fourth, we must ensure the healthy operation of the economy before and after the Olympics. Fifth, try our best to prevent and control the epidemic. Finally, use the effects of the Olympic Games to vigorously develop the local economy.

\section{REFERENCES}

[1] Dang GuoChun.Countermeasures of post-Olympic Economic trough effect[J].Network wealth,2009(04):79-80.

[2] Cao Qinghua. Post-olympic Economy from the Perspective of Economics[J].Economic issue, 2008(03):17-19+46.

[3] Zhao Changjie. Analysis of post-Olympic Economic trough effect[J].Sports and Science, 2009,30(01):17-23.

[4] Kan Kejia. Research on post-Olympic Economic Trough effect and risk aversion[J].Cooperative economy and science and technology,2010(05):6-7.

[5] Xie Jianhua. Analysis of the reasons for the success of commercial operation of Beijing Olympic Games[J].Journal of Yunnan University of Finance and Economics (Social Science Edition),2009,24(05):90-91.

[6] Chen Bing. What did Japan get from the most expensive Olympics in history?[J].Xinmin weekly,2021(28):36-39.

[7] Chen Qian-qian, LIU Chen-xi, CAI Ning, CUI Jiyuan, LIU Xue-qin. Economic analysis of post-
Olympic Period[J].Scientific and technological information, 2010(11):553+570. 